\title{
Neuronutrition and Alzheimer's Disease
}

\author{
Balenahalli N. Ramesh ${ }^{1}$, T.S. Sathyanarayana Rao ${ }^{2}$, Annamalai Prakasam ${ }^{3}$, Kumar \\ Sambamurti ${ }^{3}$, and K.S. Jagannatha Rao ${ }^{1}$ \\ ${ }^{1}$ Biochemistry and Nutrition, Central Food Technological Research Institute, CSIR Unit, Mysore, \\ India \\ 2Department of Psychiatry, J S S Medical College, Mysore, India \\ ${ }^{3}$ Department of Neuroscience, Medical University of South Carolina, Charleston, South Carolina, \\ USA
}

\section{Abstract}

Alzheimer's disease (AD) is a complex neurological disorder with several unequivocally identified genetic risk factors. Among the several environmental factors proposed for $\mathrm{AD}$, dietary protective and risk factors have been most compelling. In particular, diets rich in saturated fatty acids and alcohol, and deficient in antioxidants and vitamins appear to promote the onset of the disease, while diets rich in unsaturated fatty acids, vitamins, antioxidants, and wine likely suppress its onset. Evidence suggests that diets rich in polyphenols and some spices suppress the onset of AD by scavenging free radicals and preventing oxidative damage. Metal ions are known to catalyze the production of free radicals and induce mental retardation or dementia. Several studies have also identified metals such as $\mathrm{Pb}, \mathrm{Fe}, \mathrm{Al}, \mathrm{Cu}$ and $\mathrm{Zn}$ in $\mathrm{AD}$ pathogenesis. While specific chelators have been tested for therapy, they have not been very successful probably due to late administration after brain damage has been triggered. Since several dietary polyphenols are known to chelate metals, their routine use may also be protective against the onset of AD.

\section{Keywords}

antioxidants; caloric restriction; diet; homocysteine; lipid; neurodegeneration; nutrients; oxidative stress; polyphenols; vitamins

\section{Introduction}

\begin{abstract}
Alzheimer's disease (AD) is the most common form of dementia and affects one in four individuals over the age of 85 . AD has multiple etiological factors including genetics, environmental factors, and general lifestyles [1], and its hallmark pathology includes extracellular amyloid $\beta$ protein $(\mathrm{A} \beta)$ deposition in the form of senile plaques and intracellular deposits of the microtubule-associated protein " $\tau$ " as neurofibrillary tangles in the AD brain [2]. The diagnosis of this disease is based on the characteristic idiopathic psychometric deficits upon clinical evaluation and further confirmed by post-mortem due to the presence of the characteristic lesions described above [3]. A $\beta$ is produced by sequential proteolytic processing of a larger $\mathrm{A} \beta$ protein precursor ( $\mathrm{A} \beta \mathrm{PP}$ ) by $\beta$-secretase to generate a large secreted fragment
\end{abstract}

Correspondence to: K.S. Jagannatha Rao, Central Food Technological Research Institute, CSIR Unit, Mysore, 570020 India; kjr5n@yahoo.co.in.

Authors' disclosures available online (http://www.j-alz.com/disclosures/view.php?id=57). 
sAPP $\beta$ and a 99 aa cellular fragment - CTF $\beta$ - that includes A $\beta$, the transmembrane domain and the intracellular domain of A $\beta P P$ [4].

Recently, there has been increasing support for a role of diets in AD [5-7]. A number of dietary factors such as saturated fatty acids [8], higher calorie intake [9], and excessive alcohol [10] have been reported to increase the risk of dementia and AD. In contrast, antioxidants, fish, methionine-rich proteins, and vitamins were identified as protective against the disease [11]. Thus the global variation in diet may be linked to differential prevalence of AD [12]. Several cross-sectional studies suggest a relationship between particular nutrients and the presence of cognitive changes [5-7]. However, these need to be confirmed at an experimental level [13].

Interestingly, the same dietary pattern of risk and protection has been long accepted for metabolic syndrome and cardiovascular risk. In agreement Diabetes and hyperinsulinaemia are considered as important risk factors for AD [14]. Among the other risk factors, depressive illness, traumatic head injury [15], cardiovascular disease [16-17], smoking [18-19], and stroke [20-21] are significant issues that may be related to the same risk factors. Further, the $\varepsilon 4$ allele variant of apolipoprotein E (ApoE) has been associated with increased risk in sporadic and familial AD [22]. As a carrier of cholesterol, ApoE- $\varepsilon 4$ is also a risk factor in cardiovascular disease.

Oxidative stress has been suggested to play a major role in the pathology of AD [23-26], and evidence for its mediation includes: 1) generation of free radicals through metal ions; 2) enhanced lipid peroxidation; 3) increased DNA and protein damage; and 4) increased tau protein phosphorylation [26]. The human body has a defense mechanism to cope with oxidative stress, or prevent the onset of oxidative stress, through endogenous antioxidants derived from enzymatic or non-enzymatic sources [27], namely superoxide dismutase, glutathione reductase, and catalase. The nonenzymatic sources of endogenous antioxidants include glutathione, uric acid, $\alpha$-lipoic acids, acetyl L-carnitine, melatonin, and dehydroepiandrosterone. Endogenous antioxidants also include the products of reactions catalyzed by enzymes that are up regulated in response to oxidative stress (e.g., bilurubin) [27]. Dietary antioxidants and metal chelators were found to be associated with a reduced AD risk further reinforcing the importance of dietary stress on the body's homeostasis pathways and nutritional guidelines for AD prevention.

Several studies demonstrate that diet has a definite long-term effect on general health [21, 32]. Although several cross-sectional studies have indicated that diet also plays a role in AD, the long time taken for the pathogenesis of AD makes it nearly impossible to experimentally demonstrate the specific effects of diets in AD. In this review, we attempt to define the action of presumably protective and harmful dietary habits on pathways identified as relevant to AD pathogenesis. A common theme that has emerged from the analysis is that aging and AD are associated with excesses in saturated lipids, homocysteine, oxidative stress and other toxic pathways that appear to result from reduced efficiency of clearance pathways in general. Thus, a general rule of $\mathrm{AD}$ is that moderation is key to disease prevention. However, literature also suggests that several specific additions to the diet also help in AD prevention.

We will discuss the major dietary factors involved in maintaining homeostasis and energy requirements such as calorie restriction, lipids, metal chelators, vitamins and other special dietary supplements such as red wine and spices.

\section{Caloric Restriction (CR) and AD}

The first lesson in moderation comes from calorie restriction. Energy requirements decline progressively after early adulthood, because of cessation of growth and a decrease in basal metabolic rate and physical activity. The average energy requirement for an adult is $25 \mathrm{kcal} /$ 
$\mathrm{kg} / \mathrm{day}$ whereas for children it is the sum of $100 \mathrm{kcal} / \mathrm{kg} / \mathrm{day}$ for the first $10 \mathrm{~kg}, 50 \mathrm{kcal} / \mathrm{kg} / \mathrm{day}$ for the second $10 \mathrm{~kg}$ and $20 \mathrm{kcal} / \mathrm{kg} /$ day beyond $20 \mathrm{~kg}$ [29] It has been shown that calorie allowances will be reduced by $5 \%$ per decade between 35 and 55, $8 \%$ per decade between 55 and 75 and a further $10 \%$ beyond 75 years of age although this may vary considerably based on physical activity and other characteristics [30].

Dietary excess is known to influence the onset and progress of age related diseases like diabetes, obesity and vascular diseases and actually has been shown to reduce life-spans [31-33]. CR known to reduce the production of reactive oxygen species in animals by modulating neuroinflammation and oxidative stress [34-36], and CR is reported to have neuroprotective effects in young rodent models of neurodegenerative disease [37-38]. Furthermore, CR activates intercellular neurotrophic signaling mechanisms and thus provides neuroprotection [39]. Recent studies strongly suggest a link between diets and AD leading to the notion that CR may delay or prevent $\mathrm{AD}[9,40-43]$. There is still a debate about whether CR works to increase life span, and by extension, other benefits in humans although the bad effects of dietary excess remain unchallenged [44]. Nevertheless, data from population based studies suggest that a lower calorie intake leads to a lowered risk of $\mathrm{AD}$ and $\mathrm{PD}[9,37,45]$.

$\mathrm{CR}$ is known to induce neuroprotective molecules that have a role in resistance of neurons to oxidative, metabolic, excitotoxic and apoptotic insults [44,46-48]. CR is known to induce expression of several different neurotrophic factors like brain derived neurotrophic factor (BDNF) in brain cells [43]. Rats maintained on CR shows increased levels of brain-derived neurotrophic factor in neurons in cerebral cortex, hippocampus, and striatum [48-49]. BDNF has been reported to have role in enhancing memory and learning, and protects neurons against oxidative and metabolic insults and is also known to stimulate neurogenesis [48-49]. Studies also show reduced levels of brain-derived neurotrophic factors in patients with $\mathrm{AD}$ and PD [50-51]. There is a substantial amount of data accumulating in favor of increase in life span by stimulating silent mating type information regulation-2. The silent mating type information regulation-2 is required in some species for enhanced life span [52]. CR has also been demonstrated to be capable of reducing the amyloid and NFT lesion load of animal models suggesting that it may directly affect the pathogenesis of AD [53-54]. However, there is a need for more data generation on calorie restriction and its benefits to the brain. The mechanism by which CR modulates $\mathrm{AD}$ is not clear, however, it is postulated that $\mathrm{CR}$ increases synaptic plasticity, anti-inflammatory mechanisms and inducing neuroprotective factors [55]. CR was shown to protect the age-related loss of neurons in $\mathrm{AD}$ [56]. They also observed that CR could reduce the enlargement of ventricles, caspase activation and astrogliosis [56]. From the above findings it indicated that CR could increase neurogenesis [57] but, before we come to consensus, we should also analyze and quantify the long-term effects of CR in adults [55].

However, before rushing to advocate $\mathrm{CR}$ as a treatment paradigm it is important to recognize that the treatment may be too late and even be counterproductive. AD patients commonly develop abnormal eating behaviors [58] that include anorexia nervosa and bulimia nervosa [59]. Studies indicate that dietary intake of nutrients is poor in older adults who convert to early stage $\mathrm{AD}$ as compared to their cognitively intact counterparts [60]. Indeed weight loss may be an early indicator of AD prior to dementia [61].

It is important to emphasize that little is known about the factors correlated with eating difficulties in AD. Riviere and colleagues [59] conducted a one-year investigation to understand the factors responsible for adverse eating behavior among $\mathrm{AD}$ patients living at home with caregivers. This study involved 224 patients and their caregivers. Eating difficulties were assessed using the eating "Dependency Scale and Averse Eating Behavior Inventory". The study found two significant associations which include: i) eating difficulties and age of the caregivers and ii) severity of the disease and psychological function of the patients [59]. 
They analyzed the data using the regression analysis and found positive correlation between adverse eating behavior and initial caregivers burden. There was, however, an inverse correlation between memory impairment and adverse eating behaviors. Thus, both cognitive impairment and family stress can help in predicting that $\mathrm{AD}$ patients living at home develop adverse eating behavior.

\section{Lipids and AD}

Lipids have two major functions in the cell: they are reservoirs of chemical energy stored as fat and they are the structural components of cell membranes. Lipids also act as signaling molecules through steroid hormones and eicosanoids. Lipid metabolism plays a key role in $\mathrm{AD}$ through the ApoE- $\varepsilon 4$ allele, one of the genetic risk factors for $\mathrm{AD}$ [62-65]. The transport of lipid in blood, brain and cerebrospinal fluid is modulated by ApoE [64,66]. There is also an important association between dietary factors and ApoE polymorphisms, which gives a clue as to why we should consider dietary fat uptake patterns in different populations [67]. There is a hypothesis that one dose of e 4 allele in the brain increases $\mathrm{AD}$ risk by 2-3 times, two doses of $\varepsilon 4$ allele provides a 12-15 times higher risk [68-69].

An interesting study has been conducted to assess the risk factors throughout adult life based on a life history questionnaire; it includes medical, occupation, activity level, education, smoking and dietary habit questions [70]. The investigations have obtained lifestyles pattern for three age groups: $20-39,40-59$ and $60+$ or 5 years prior to AD diagnosis for cases. They indicated that healthy controls with the ApoE $\varepsilon 4$ allele consumed less total and saturated fat between the ages of 20 and 60 years than those without the $\varepsilon 4$ allele [70]. The consumption of higher fat through diet during mid-life may therefore reduce the risk for AD than for those without the e 4 allele. This may indicate a protective effect of the ApoE $\varepsilon 2$ allele and $\varepsilon 3$ allele due to the modulating effects of ApoE on LDL cholesterol level [71-72]. The intake of nonhydrogenated unsaturated fats, low intake of hydrogenated and saturated fats and high intake of n-3 polyunsaturated fatty acids from fish or vegetable sources may lower the risk of vascular dementia as well [73].

A relationship between reduced risk of $\mathrm{AD}$ and a diet rich in docosahexaenoic acid (DHA) and omega-3 essential polyunsaturated fatty acid was reported [74]. Furthermore, a possible role for DHA in preventing lipid peroxidation and in reducing the accumulation of $A \beta$ in the corticohippocampal region in the mouse model was hypothesized [75]. It has also been shown that DHA plays a role in the expression of signal transduction molecules [76]. Additionally, DHA is known to stimulate the expression of transthyretin, a protein involved in the transport of thyroxin. Transthyretin has an affinity for $A \beta$ and possibly stimulates the clearance mechanism of $A \beta$ [77]. These observations support the need for further research to understand the therapeutic potential of DHA in AD.

Cholesterol is present in specialized membranes of myelin and in the membranes of neuronal and glial cells present in the brain (approximately $25 \%$ of the total cholesterol of the human body) [78-82]. Alterations in the metabolism of cholesterol are reported to be associated with age [83-88] and have been shown to play a role in the pathogenesis of AD [89-91]. Recent reports show a link between cholesterol and A $\beta \mathrm{PP}$ processing pathways [92-93]. An increase in dietary cholesterol levels increase secreted $\mathrm{A} \beta \mathrm{PP}$ derivatives, namely $\mathrm{sA} \beta \mathrm{PP} \alpha$ and sA $\beta$ PP $\beta$ in mouse brain and modulate the levels of major secreted $A \beta$ forms $A \beta_{40}$ and $A \beta_{42}$ $[92,94]$ Recent studies suggest that $\beta$ - and $\gamma$-secretase may be regulated by isoprenoid that are synthesized in the cholesterol biosynthesis pathway in addition to cholesterol [95-96].

Transgenic mouse models over expressing human A $\beta \mathrm{PP}$, and maintained on a diet rich in saturated fats and cholesterol, have shown an increased accumulation of $A \beta$ alone or in combination with other AD-related proteins [97]. Additionally, the dietary fats (saturated fat, 
hydrogenated fat and cholesterol) are reported to be involved in the impairment of memory and hippocampal pathology in the rat brain [98]. Conversely, inhibition of cholesterol synthesis reduces amyloid load.

Though the etiology of AD is still elusive, reports have strongly linked the role of cholesterol and ApoE in A $\beta P P$ processing. Elevated levels of saturated fatty acids in AD and its role in hyperphosphorylation of tau were reported [99]. To examine free fatty acid induced hyperphosphorylation of tau, they studied primary rat cortical neurons in untreated (control) and treated neurons with $0.2 \mathrm{mM}$ of either palmitic or stearic acids for $24 \mathrm{~h}$. The findings indicated that astroglia mediated oxidative stress is found to be involved in free fatty acidinduced hyperphosphorylation of tau in primary neurons. Further, it was reported that saturated fatty acids might induce aggregation of tau, as well as $A \beta$ [99]. A study indicated that higher intake of saturated fatty acids may be a risk factor for $\mathrm{AD}$ [100]. However, the question is whether or not a higher intake of polyunsaturated fatty acids and monounsaturated fatty acids will reduce the risk for AD. A word of caution is the quantity of uptake of polyunsaturated fatty acids and monounsaturated fatty acids, and their link to atherogenesis. As an example, a high intake of linoleic acid, which is $n-3$ polyunsaturated fatty acids, may increase the susceptibility of LDL cholesterol to oxidation leading to atherogenesis [101]. The recent report suggests that diet rich in omega-3 fattyacids or use of fish oil supplements (DHA and EPA), did not protect against AD. But the dietary fish may contain nutrients, other than DHA and EPA, that may provide some protection against AD [102].

In conclusion, lipids have a complex relationship with $\mathrm{AD}$. Some appear to be protective whereas others such as cholesterol appear to be harmful. The relationship is however even more complex with some of the effects of cholesterol attributable to intermediates in cholesterol biosynthesis such as isoprenoids. Interestingly, the relationship between AD and cholesterol epidemiology is complex with almost no difference between normal controls and AD.

However, high levels of cholesterol in middle age has been linked to higher risk for AD in later life[103]. Further complicating the picture is the finding that high cholesterol late in life is actually linked to a reduction in AD risk [104] suggesting that $\mathrm{AD}$ is likely linked to a rapid loss of cholesterol with age [105].

\section{Metal Chelators in AD}

The brain is rich in unsaturated fatty acids, and thus it is prone to oxidative stress. Redox-active metals such as $\mathrm{Fe}$ and $\mathrm{Cu}$ are involved in the production of reactive oxygen species in the brain, and the levels of $\mathrm{Fe}$ and $\mathrm{Cu}$ are high in brain tissues. Oxidative stress is a process leading to the production of reactive oxygen species, where it causes molecular damage leading to altered biological functions [106]. Moreover, $\mathrm{Fe}$ and $\mathrm{Cu}$ are implicated in the formation of oxygen free radicals and damage tissue in AD brain [107]. Fe accumulates in neurofibrillary tangles (NFTs) as well as in A $\beta$ deposits [108]. Aluminum (Al) also accumulates in NFT-containing neurons [109-110] and is found to stimulate Fe-induced lipid peroxidation [111]. There are reports on increased levels of $\mathrm{Zn}$ (II), $\mathrm{Fe}$ (III), and $\mathrm{Cu}$ (II) in the neuropil and senile plaques in the $\mathrm{AD}$ brain [112]. $\mathrm{Al}$ is also known to aggravate the free radical damage already initiated by Fe [113].

Interestingly, metals such as $\mathrm{Cu}$ (II) appear to facilitate the cholesterol-mediated increase in amyloid pathology [114]. Early exposure to $\mathrm{Pb}$ is also implicated in increased amyloidosis by increasing APP expression [115]. Several dietary spices are known to act as metal chelators and may therefore be protective against dementia [116]. 


\section{Vitamin E and AD}

The body's defensive system against oxidative stress includes molecules called antioxidants that are also known as free radical scavengers. There is still a debate regarding the role of reactive oxygen species related to neuronal damage. Considering that oxidative stress can be a primary event, the role of dietary antioxidants in combating oxidative stress in AD is discussed below. Additionally, the dysregulations of metabolic pathways in the aged brain will lead to reduced synthesis of defense molecules to combat oxidative stress. The major questions a still to be understood are: What are the regulatory molecules of the metabolic pathways in aged brain that are susceptible to oxidative damage? What are the homeostatic mechanisms make neurons resistant to oxidative damage?

Studies have reported the role of antioxidants in lowering the risk of stroke and AD [117-120]. The change in the concentration of antioxidants in neurodegeneration may be a primary or secondary event in relation to dietary intake [120]. Studies have established a relationship between the plasma concentration of antioxidants and cognition [121-122]. Studies indicate that the various antioxidant supplements could be effective in reducing oxidative stress [123-124].

Notably, the level of vitamin $\mathrm{E}$ in plasma of AD patients is $18.65 \pm 3.62 \mathrm{mmol} / \mathrm{L}$ compared to age-matched controls $30.03 \pm 12.03 \mathrm{mmol} / \mathrm{L}$ [125-126]. It has been shown that long term feeding of rats (from 6 to 15 months of age; F344 rats) with a supplemented AIN-93 diet (strawberry or spinach extract (1-2\% of the diet) or vitamin E (500 IU), have protected against age-related changes in cognitive functions. Furthermore, the supplemented diet could prevent the onset of age related deficits in several indices, including cognitive behavior and performance with the Morris water maze [125-126]. However, Petersen and colleagues [127] indicated that vitamin $\mathrm{E}$ had no beneficial effect in patients with mild cognitive impairment [127]. In a double blind study [127], subjects with mild cognitive impairment were given 2000 IU of vitamin E daily, $10 \mathrm{mg}$ donepezil daily, or a placebo for three years. The overall rate of progression from mild cognitive impairment to full clinical AD was $16 \%$ per year, and, importantly, there was no difference between subjects on the placebo and subjects who received vitamin E over a period of three years. These studies disagree on the validity of vitamin supplements to AD patients and, thus, more research is essential to understand further.

Researchers across the globe are interested in elucidating the protective potential of vitamin $\mathrm{E}$ and vitamin $\mathrm{C}$ against $\mathrm{AD}$ [128]. In another major study, $\mathrm{AD}$ patients were given 2,000 IU of vitamin $\mathrm{E}$ per day, a dose that exceeds the recommended daily allowance of vitamin $\mathrm{E}$. They found that a higher dose of vitamin $\mathrm{E}$ is able to delay the admission to a nursing home by six months, compared to those taking a placebo [128]. The question is to understand the quantity of vitamins required in reducing the risk of $\mathrm{AD}$ and safety of vitamin $\mathrm{E}$ at higher concentrations. Further, the dietary supplements of vitamin $\mathrm{E}$ fail to provide better results compared to dietary intake of vitamin E [129]. If the supplements are less beneficial than dietary vitamin $E$, what is the main reason for such a difference? The probable reason might be the composition of the diet, which has a cumulative and synergistic effect in the vitamin bioavailability. The apparent protection provided by dietary vitamins $\mathrm{E}$ and $\mathrm{C}$ could be by synergy due to other substances in fruits and vegetables, such as flavonoids, which have both anti-inflammatory and antioxidant properties [130].

The clinician should diagnose the plasma concentration of antioxidants at a particular point of $\mathrm{AD}$ grading and make a decision on recommending the use of vitamin $\mathrm{E}$ supplements. 


\section{Vitamins and Homocysteine Interrelations}

Hyperhomocysteine levels induce neurologic abnormalities such as cerebral atrophy, and seizures, etc. [131]. A deficiency of vitamins is found to elevate the concentration of homocysteine, which is implicated in vascular mechanisms leading to $\mathrm{AD}$ [131-132]. Vitamins like folate, B6, and B12 have been involved in the biosynthesis of amino acids, which contain sulphur, methionine, and cystein [133]. Folate and vitamin B12 are involved in biosynthesis of methionine from its precursor homocysteine, whereas, B6 has a role to play in the conversion of homocysteine to cysteine. The levels of homocysteine in the blood are elevated with ageing and age is one of the risk factor for $\mathrm{AD}$ [134]. The factors like folic acid and caloric intake are also known to modulate the plasma homocysteine [134]. There is an inverse relationship between plasma folic acid and homocysteine, and dietary folic acid is found to lower homocysteine levels. Additionally, calorie restriction is also found to decrease homocysteine levels, but the magnitude of the effect is moderate [135]. There are higher homocysteine levels in the patients with deficient in enzyme cystathione $\beta$ synthase, which is involved in catabolism of cystein. A study has shown that in mice fed in a diet with reduced levels of folic acid, there is hipppocampal pyramidal neuronal degeneration [136]. This may be because of the elevated levels of homocysteine in mice due to low folic acid. Also, administration of homocysteine into the brain is found to enhance neuronal degeneration [137], and elevated levels of homocysteine induce accumulation of DNA damage in neurons [135-136,138]. This may be because increased homocysteine induces a deficiency of methyl donors, which has implication on uracil misincorporation and oxidative damage to DNA bases [136,138]. A link between levels of homocysteine and gene expression was also reported and increased homocysteine leads to decrease in the levels of methyl donors, causing hypomethylation of PS1 promoter [139]. It is likely to alter the gene expression as gene silencing is mediated by the methylation of the promoter [139]. Fig1 represents the details of homocysteine and neuron cell death. A number of studies suggest that homocysteine can increase amyloid load in transgenic mice [140]. All the above events provide insights into the relationship between dietary intake of vitamins and homocysteine and their effect in neuronal cell death. We therefore hypothesize a relationship between vitamins, homocysteine and neuronal dysfunction. The increased levels of homocysteine in $\mathrm{AD}$ patients are a risk factor. Higher homocysteine levels cause insufficient DNA repair and point mutations, which leads to the accumulation of DNA damage and cell death. A reduction in the levels of homocysteine can be brought about by increasing cysteine levels in the body through the use of vitamin B6, which acts as a cofactor in the transformation of homocysteine to cysteine or by recycling it back to methionine using vitamin B12 and folate. Indeed, a deficiency in vitamin B12 leads to a form off dementia that resembled AD in clinical presentation and can be reversed by diet.

\section{Dietary Polyphenols and AD}

Polyphenols are natural substances that are present in plants, and their quantities vary in leaves, flowers, vegetables, and fruits. Considerable amounts of these compounds, moreover, are present in olive oil and red wine [141]. Among the polyphenols, flavonoids occupy the largest group [27]. The major component of green tea flavanoids, EGCG, for instance, has recently been shown to have neuroprotective functions such as antioxidation, iron chelation, and antiinflammation [142]. Specifically, the abundant phenolic hydroxyl groups on the aromatic ring confers the antioxidant activity, and the 3-OH group is essential for iron chelating activity of these compounds [143-144]. Similarly, the Mega Natural grape seed polyphenolic extract (GSPE), derived from grape seed, significantly inhibits oligomerization of $A \beta$ and restores the cognitive deterioration [145]. These trends ultimately provide a clue that polyphenols can be good intervention molecule for neurodegeneration. 
Tea polyphenols have been found to be potent scavengers of free radicals [146-147]. EGCG contains three heterocyclic rings, A, B, and C, and the free radical scavenging property of EGCG is attributed to the presence of trihydroxyl group on the B ring and the gallate moiety at the $3^{\prime}$ position in the C ring. EGCG is also known to chelate transition metal ions like iron and copper [142]. There are two sites where metal ions bind to the flavonoid molecule: 1) odiphenolic group in the $3^{\prime}, 4^{\prime}$-dihydroxy positions in the B ring, and 2) keto structure 4-keto, 3hydroxy in the C ring of flavonols [143,148]. Further, EGCG is found to have role in elevating the activity of two major antioxidant enzymes, superoxide dismutase, and catalase in the mouse striatum [149]. Finally EGCG treatment has been reported to modulate A $\beta P P$ processing to $\mathrm{A} \beta[150]$. The mechanisms regarding oxidative stress and its augumentation by EGCG are highlighted in fig2.

\section{Wine and AD}

A number of researchers have explored the relationship between alcoholic beverages and $\mathrm{AD}$ [151-155]. Studies have shown that frequent alcohol uptake in rats can result in mitochondrial dysfunction in neurons leading to neurodegeneration [156]. In contrast, it is reported that moderate alcohol uptake is related to a lower risk of clinical stroke [157]. Thus, alcohol may have paradoxical and competing effects in the brain; it lowers the risk of cerebrovascular disease and also likely acts as a neurotoxin. Researchers have shown a relationship between alcoholic drinks and AD [8,151-153,155]. A study of people aged 65 years and older showed that alcohol consumption of one to six drinks a week, regardless of the type of beverage used, lowered the risk of AD compared to abstainers [152]. In another study, people who consumed three servings of alcohol a day had a low risk of AD compared to those who were never exposed to alcohol [151]. An interesting study involving individuals aged 65 years and older found that monthly or weekly intake of wine, but not other alcoholic drinks, was associated with a lower risk of dementia including AD $[155,158]$. Most of the results obtained in the above studies were not statistically significant, given the small number of elderly people participating in the studies.

However, several epidemiological studies have shown that moderate wine consumption reduces the risk of developing $\mathrm{AD}[8,155,158-159]$. Wine contains antioxidants such as resveratrol, a flavonoid, which is not present in beer or other spirits. Resveratrol occurs in abundance in grapes and red wine [141,160]. The beneficial effect of wine consumption on the neurodegenerative process is therefore attributed to resveratrol [141,160-162], and resveratrol was reported to reduce $A \beta$ production in cell line HEK293 expressing wild type or Swedishmutant APP695 [162]. Additionally, studies indicate the involvement of resveratrol in proteosome clearance of $A \beta$; decreases in its presence reduce $A \beta$ clearance and reduce toxicity in $\mathrm{AD}$ brains. The proteosome is an ubiquitin activated protein quality control system that enzymatically labels, transports, and finally degrades misprocessed and misfolded protein [163]. While a number of possible functions of the proteosome in the regulation of $A \beta$ metabolism have been ascribed to the multicatalytic complex of proteosomes [163], additional studies are needed to understand the role of the proteosome in the clearance of $A \beta$. There is also a need to understand whether it is specific for the monomer, oligomer, or the protofibril, and this is not clearly known.

No reduction in the activity of $\gamma$-secretase mediated-cleavages of A $\beta \mathrm{PP}$ in the presence of resveratrol was found [162]. Thus, it excludes the possibility that resveratrol lowers $A \beta$ by promoting the proteosomal degradation of $\mathrm{C} 99$ (C terminal fragment of A $\beta \mathrm{PP}$ upon cleavage by $\mathrm{BACE}$ ). Recent evidence also suggests that $\mathrm{A} \beta$ can be degraded by proteosome-dependent endoplasmic reticulum (ER)-associated degradation. However, ER A $\beta$ represents a small fraction of the total $A \beta$ produced, and it appears to be controlled by ER-associated degradation and not resveratrol. There is no clear-cut indication on the effect of resveratrol on the 
mechanism of clearance of $A \beta$ levels in the neurons, although resveratrol may have an effect on key players (components) in the A $\beta$ clearance pathway [162]. Resveratrol was also found to interact with other proteins, including members of the sirtuin family. Sirtuins are deacetylases with a role in cellular longevity [164]. It is also known that resveratrol acts as a potent activator of the human sirtuin 1 in vitro [165]. Moreover, activation of sirtuin 1 by resveratrol has been linked to neuroprotective pathways [165]. Therefore, it would be of interest to understand whether sirtuin mediates the resveratrol-induced decrease of $A \beta$. However, it is not clear whether a decrease in activity of the proteosome parallels an increase of $A \beta$ levels [166]. Further, it has been shown that resveratrol selectively activates the proteosome in the anti-amyloidogenic pathway [166].

Antioxidant effects of flavonoids also include transcriptional upregulation of antioxidant enzymes such as glutathione synthesizing enzymes. There is also a report interlinking the inhibitory effect of flavonoids on 5-lipoxygenase, which is involved in lipid peroxidation [166]. However, it seems reasonable not to recommend alcohol intake to those who are potentially at risk for abuse and addiction [167]. Fig 3 depicts the importance of resveratrol, in particular, in modulating neurodegeneration. Resveratrol favors phosphorylation in PKC, and this activates the non-amyloidogenic pathway of A $\beta \mathrm{PP}$ cleavage, which leads to reduction in $\mathrm{A} \beta$ release. $\mathrm{sA} \beta \mathrm{PP} \alpha$, which is a product of $\mathrm{A} \beta \mathrm{PP}$ cleavage, becomes translocated to the nucleus and may induce genes involved in neuroprotection. Resveratrol also nonspecifically stimulates the proteosome, which helps in clearing $\mathrm{A} \beta$ and in turn reduces neuronal cell death. The oral ingestion of resveratrol by rodents and humans showed that resveratrol absorbs readily into the system, appearing in plasma (total resveratrol which includes both modified and unmodified resveratrol) [168-173]. The major drawback in using resveratrol in modulation of neurodegeneration is its low bioavailability [174]. It has been demonstrated that mice fed with feasible dosages of resveratrol for 45 days either showed the presence of resveratrol or its metabolites in the brain indicating bioavailability to brain [174].

As stated above, the Mega Natural grape seed polyphenolic extract, a commercial formulation of polyphenolics derived from grape seed, significantly inhibited oligomerization of $A \beta$ [175]. The extract was also shown to have the ability to inhibit the cytotoxicity of $A \beta_{40} /$ $\mathrm{A} \beta_{42}$ in PC12. Furthermore, the extract significantly restored the cognitive deterioration in $\mathrm{Tg} 2576$ transgenic mice [175].

\section{Dietary Spices and AD}

The Indian diet is rich in spices including red chili, coriander, turmeric, etc. Turmeric, a yellow curry spice, is widely used as a food preservative and herbal medicine in India [176], and notably, the prevalence of AD patients in India between 70 and 79 years of age is 4.4 fold less than that of the United States [177]. We hypothesize that this is partially attributed to turmeric consumption in India as a result of its curcumin contents.

Inflammation of the brain due to injury or disease is mediated by microglia [178]. Brain inflammation is also mediated by activation of the complement system. AD involves a chronic central nervous system inflammatory response that is associated with both head injury and $\mathrm{A} \beta$ pathology [179]. For example, prolonged use of non-steroidal anti-inflammatory drugs, statins and ibuprofen, have reduced inflammation in the AD brain [180]. The main disadvantage of the use of non-steroidal anti-inflammatory drugs in $\mathrm{AD}$ is their toxicity to the gastrointestinal tract, liver, and kidney. Non-steroidal anti-inflammatory drugs are also found to inhibit cyclo-oxygenase I [181-182]. Researchers are involved in finding alternatives to nonsteroidal anti-inflammatory drugs. One such phenolic antioxidant alternative is curcumin, derived from yellow curry spice, which is found to have an anti-inflammatory effect. Curcumin is a potent free radical scavenger, better than vitamin $\mathrm{E}$, and it provides protection against lipid 
peroxidation [183] and acts as a scavenger of nitric oxide radicals [184]. Curcumin also decreases the overall insoluble amyloid plaque burden in an animal model [184]. In an intraventricular $A \beta$ infusion rat model, dietary curcumin reduced an isoprostane index of oxidative damage, amyloid plaque burden, and $\mathrm{A} \beta$-induced spatial memory deficits in the Morris water maze [185]. Studies have shown that curcumin reduces inflammation and oxidative damage in the brain of $\mathrm{Tg} 2576 \mathrm{~A} \beta \mathrm{PPSw}$ transgenic mice [186-187]. The low, nontoxic doses of curcumin decreases the levels of soluble and insoluble $A \beta$ and plaque burden in many affected brain regions. Moreover, cell culture experiments with human embryonic kidney (HEK) 293 cells indicated that fibrillar A $\beta$ (fA $\beta$ ) are destabilized by nordihydroguaiaretic acid [188]. Thus, it may be reasonable to speculate that bioactive molecules like curcumin, rosmanaric acid, and nordihydroguaiaretic acid could possibly prevent the onset of $\mathrm{AD}$, not only by scavenging reactive oxygen species, but also by inhibiting fA $\beta$ deposition in the brain.

Curcumin also protects mouse brain from oxidative stress caused by 1-methyl-4-phenyl-1, 2,3,6-tetrahydropyridine [189] and has also been reported to attenuate 3-nitropropionic acidinduced neurotoxicity [190]. In rat brain, curcumin protects against lead- and cadmium-induced lipid peroxidation as well as lead-induced tissue damage [191]. Fig.4 highlights the diverse effects of curcumin in combating neurodegeneration. Curcumin has multiple biological effects. It chelates transition metals ( $\mathrm{Fe}$ and $\mathrm{Cu}$ ) and acts as an antioxidant and anti-inflammatory molecule. It also acts as an antioxidant by scavenging reactive oxygen species, which will prevent oxidative damage to macromolecules, thereby reducing neuronal cell death.

\section{Diet and Genes in AD}

Diet-genetic interactions may play an important role in healthy aging [38]. Lifestyles include dietary patterns during early, middle, and adult life that may influence the risk of brain disorders. Genetic factors include mutations in genes like amyloid precursor protein, presenilin 1 , and presenilin 2 that are risk factors and cause early onset events in AD. Research related to the effect of dietary molecules on the expression of A $\beta P P$ gene and its processing to produce $\mathrm{A} \beta$ has not been done. The scope of the dietary molecules on $\mathrm{AD}$ can also be extended for stimulating $A \beta$ clearance mechanisms of cells. APOE 44 is the most important genetic risk factor for AD and cardiovascular diseases [192-193]. Dietary molecules may affect genes independently or through signaling molecules. APOE $\varepsilon 4$ also been associated with cognitive decline [194-195]. The genotype APOE $\varepsilon 4$ has a differential effect on fat consumption in different stages of human life. Importantly, there are limits to commenting on dietary-gene interactions and more data is required to arrive at conclusion.

\section{Dietary Recommendation for AD Patients}

Recommending a diet for $\mathrm{AD}$ patients must be done by careful clinical observations. To date, there is no report of a perfect diet for the different categories of $\mathrm{AD}$ patients such as those with initial onset, mild cognitive decline and final stage AD. A clear problem for patients even in the early stages of $\mathrm{AD}$ is weight loss and nutritional deficiencies as discussed earlier. Indeed weight loss may be an early predictor of the onset of AD related dementia. Many of the recommendations that may be made at this late stage need to be focused towards maintaining the health of the patient. It is certainly important to examine the patient for nutritional deficiencies and identify a good healthy diet to ensure good physical health. Certain vitamins such as B12 and folic acid need to be replaced to ensure that the dementia is not partially due to this deficiency. AD patients also have altered dietary preferences and dysphagia and tend to show additional weigh loss in their late stages, where the caregiver needs to be adequately counseled to reduce frailty. Nutritional information and support of family are probably the best strategies to prevent adverse eating behavior in AD to improve the patients and caregiver's 
quality of life. Inadequate attention has been paid to understanding the specific alterations in food intake in AD [196]. Indeed, at present the only advice that one may provide is to ensure adequate nutrition, physical exercise, relaxing mild treatments to reduce agitation, and enrichment of environment with music, dance etc.

Prior to the onset of dementia, there is great hope that nutritional intervention may lead to improvements in general health and prevent or delay AD. Many of the promising dietary supplements are listed in Table 1. In addition, the rule of thumb appears to be high levels of physical and mental activity coupled with dietary moderation with care to ensure the lack of nutritional deficiencies. There is a need to identify the stages of progression of $\mathrm{AD}$ that are associated with disturbed food intake patterns; in depth research is required to further such an understanding.

\section{Acknowledgments}

Our sincere thanks to Dr. V Prakash, Director, CFTRI, Mysore for his support. BNR is thankful to the University Grant Commission, India, for providing a fellowship. The authors are thankful to DBT for financial support through a research grant. We also thank NIH for grants AG022103 and AG023055.

\section{References}

1. Kalaria RN, Maestre GE, Arizaga R, Friedland RP, Galasko D, Hall K, Luchsinger JA, Ogunniyi A, Perry EK, Potocnik F, Prince M, Stewart R, Wimo A, Zhang ZX, Antuono P. Alzheimer's disease and vascular dementia in developing countries: prevalence, management, and risk factors. Lancet Neurol 2008;7:812-826. [PubMed: 18667359]

2. Lee VM. Tauists and beta-aptists united--well almost! Science 2001;293:1446-1447. [PubMed: 11520974]

3. Selkoe DJ. Alzheimer's disease results from the cerebral accumulation and cytotoxicity of amyloid beta-protein. J Alzheimers Dis 2001;3:75-80. [PubMed: 12214075]

4. Wilquet V, Strooper B. Amyloidbeta precurssor protein processing in neurodegeneration. Curr Opin Neurobiol 2004;14:582-588. [PubMed: 15464891]

5. Gasior M, Rogawski MA, Hartman AL. Neuroprotective and disease-modifying effects of the ketogenic diet. Behav Pharmacol 2006;17:431-439. [PubMed: 16940764]

6. Lau FC, ShukittHale B, Joseph JA. Nutritional intervention in brain aging: reducing the effects of inflammation and oxidative stress. Subcell Biochem 2007;42:299-318. [PubMed: 17612057]

7. Dosunmu R, Wu J, Basha MR, Zawia H. Environmental and dietary risk factors in Alzheimer's disease. Expert Rev Neurother 2007;7:887-900. [PubMed: 17610395]

8. Hooijmans CR, Kiliaan AJ. Fatty acids, lipid metabolism and Alzheimer pathology. Eur J Pharmacol 2008;585:176-196. [PubMed: 18378224]

9. Luchsinger JA, Tang MX, Shea S, Mayeux R. Caloric intake and the risk of Alzheimer disease. Ach Neurol 2002;59:1258-1263.

10. Panza F, Capurso C, Solfrizzi V. Alcohol use, thiamine deficiency, and cognitive impairment. JAMA 2008;299:2853-2854. [PubMed: 18577726]

11. Kalmijn S, Feskens EJ, Launer LJ, Kromhout D. Polyunsaturated fatty acids, antioxidants, and cognitive function in very old men. Am J Epidem 1997;145:33-41.

12. Grant WB. The APOE-epsilon4 allele and Alzheimer disease among African Americans, Hispanics, and whites. JAMA 1998;280:1662-1663. [PubMed: 9831994]

13. Launer LJ, Brock DB. Population-based studies of AD: message and methods: an epidemiologic view. Stat Med 2004;23:191-197. [PubMed: 14716721]

14. Strachan MW. Insulin and cognitive function. Lancet 2003;362:1253. [PubMed: 14575966]

15. Mayeux R, Stern Y, Ottman R, Tatemichi TK, Tang MX, Maestre G, Tycko NC, Schofield PW, Tang M, Marder K, Bell K, Dooneief G, Lantigua R, Wilder D, Gurland B, Stern, Mayeux R. Consistency of clinical diagnosis in a community-based longitudinal study of dementia and Alzheimer's disease. Neurology 1995;45:2159-2164. [PubMed: 8848185] 
16. Abellan G, Van Kan, Rolland Y, Nourhashemi F, Coley N, Andrieu S, Vellas B. Cardiovascular disease risk factors and progression of Alzheimer's disease. Dement Geriatr Cogn Disord 2009;28:240-246.

17. Luchsinger JA, Mayeux R. Dietary factors and Alzheimer's disease. Lancet Neurology 2004;3:579_ 587. [PubMed: 15380154]

18. Ott A, Slooter AJ, Hofman A, vanHarskamp F, Witteman JC, Van Broeckhoven C, vanDuijn CM, Breteler MM. Smoking and risk of dementia and Alzheimer's disease in a population-based cohort study: the Rotterdam Study. Lancet 1998;351:1840-1843. [PubMed: 9652667]

19. Merchant C, Tang MX, Albert S, Manly J, Stern Y, Mayeux R. The influence of smoking on the risk of Alzheimer's disease. Neurology 1999;52:1408-1412. [PubMed: 10227626]

20. Honing LS, Tang MX, Albert S, Costa R, Luchsinger J, Manly J, Stern Y, Mayeux R. Stroke and the risk of Alzheimer disease. Arch Neurol 2003;60:1707-1712. [PubMed: 14676044]

21. Vermeer SE, Prins ND, denHeijer T, Hofman A, Koudstaal PJ, Breteler MM. Silent brain infarcts and the risk of dementia and cognitive decline. The N Eng J Med 2003;348:1215-1222.

22. Mayeux R, Stern Y, Ottman R, Tatemichi TK, Tang MX, Maestre G, Ngai C, Tycko B, Ginsberg H. The Apolipoprotein epsilon 4 allele in patients with Alzheimer's disease. Ann Neurol 1993;34:752754. [PubMed: 8239575]

23. Aksenov MY, Aksenova MV, Butterfield DA, Geddes JW, Markesbery WR. Protein oxidation in the brain in Alzheimer's disease. Neuroscience 2001;103:373-383. [PubMed: 11246152]

24. Markesbery WR. Oxidative stress hypothesis in Alzheimer's disease. Free Radic Biol Med 1997;23:134-147. [PubMed: 9165306]

25. Markesbery WR, Carney JM. Oxidative alterations in Alzheimer's disease. Brain Pathol 1999;9:133146. [PubMed: 9989456]

26. Sayre L, Smith MA, Perry G. Chemistry and biochemistry of oxidative stress in neurodegenerative disease. Curr Med Chem 2001;8:721-738. [PubMed: 11375746]

27. Butterfield D, Castegna A, Pocernich C, Drake J, Scapagnini G, Calabrese V. Nutritional approaches to combat oxidative stress in Alzheimer's disease. J Nutr Biochem 2002;13:444-461. [PubMed: 12165357]

28. Grant WB, Campbell A, Itzhaki RF, Savory J. The significance of environmental factors in the etiology of Alzheimer's disease. J Alzheimers Dis 2002;4:179-189. [PubMed: 12226537]

29. Gillenwater, JY.; Grayhack, JT.; Howards, SS.; Duckett, JW., editors. Adult and Pediatric Urology. 1991. p. 2366

30. Rovio S, Kåreholt I, Helkala EL, Viitanen M, Winblad B, Tuomilehto J, Soininen H, Nissinen A, Kivipelto M. Leisure-time physical activity at midlife and the risk of dementia and Alzheimer's disease. Lancet Neurol 2005;4:705-711. [PubMed: 16239176]

31. Sun MK, Alkon DL. Links between Alzheimer's disease and Diabetes. Drugs of Today 2006;42:481489. [PubMed: 16894402]

32. Leibson CL, Rocca WA, Hanson A, Cha R, Kokmen E, O'Brien PC, Palumbo PJ. The risk of dementia among persons with diabetes mellitus: a population-based cohort study. Ann N Y Acad Sci 1997;826:422-427. [PubMed: 9329716]

33. Peila R, Rodriguez BL, Launer LJ. Type 2 diabetes, APOE gene, and the risk for dementia and related pathologies: The Honolulu-Asia Aging Study. Diabetes 2002;51:1256-1262. [PubMed: 11916953]

34. Lee CK, Weindruch R, Prolla TA. Gene-expression profile of the ageing brain in mice. Nature Genet 2000;25:294-297. [PubMed: 10888876]

35. Morgan TE, Xie Z, Goldsmith S, Yoshida T, Lanzrein AS, Stone D, Rozovsky I, Perry G, Smith MA, Finch CE. The mosaic of brain glial hyperactivity during normal ageing and its attenuation by food restriction. Neuroscience 1999;89:687-699. [PubMed: 10199605]

36. Olgun A, Akman S, Serdar MA, Kutluay T. Oxidative phosphorylation enzyme complexes in caloric restriction. Exper Gerontol 2002;37:639-645. [PubMed: 11909681]

37. BruceKeller AJ, Muberger GU, McFall R, Mattson MP. Food restriction reduces brain damage and improves behavioral outcome following excitotoxic and metabolic insults. Ann Neurol 1999;45:815. [PubMed: 9894871] 
38. Mattson MP. Gene-diet interactions in brain aging and neurodegenerative disorders. Ann Inter Med 2003; 139:441-444.

39. Mattson MP. Emerging neuroprotective strategies for Alzheimer's disease: dietary restriction, telomerase activation, and stem cell therapy. Exper Gerontol 2000;35:489-502. [PubMed: 10959037]

40. Engelhart MJ, Geerlings MI, Ruitenberg A, VanSwieten JC, Hofman A, Witteman JC, Breteler MM. Diet and risk of dementia: Does fat matter?: The Rotterdam Study. Neurology 2002;59:1915-1921. [PubMed: 12499483]

41. Gustafson D, Rothenberg E, Blennow K, Steen B, Skoog I. An 18-year follow-up of overweight and risk of Alzheimer disease. Arch Inter Med 2003;163:1524-1528.

42. Grant WB. Obesity and Alzheimer disease: roles of diet and genetics. Arch Inter Med 2004;164:109110.

43. Mattson MP, Chan SL, Duan W. Modification of brain aging and neurodegenerative disorders by genes, diet, and behavior. Physiol Review 2002;82:637-672.

44. Lee J, Duan W, Long JM, Ingram DK, Mattson MP. Dietary restriction increases the number of newly generated neural cells, and induces BDNF expression, in the dentate gyrus of rats. J Mol Neurosci 2000;15:99-108. [PubMed: 11220789]

45. Logroscino G, Marder K, Cote L, Tang MX, Shea S, Mayeux R. Dietary lipids and antioxidants in Parkinson's disease: a population-based, case-control study. Ann Neurol 1996;39:89-94. [PubMed: 8572672]

46. Duan W, Guo Z, Mattson MP. Brain-derived neurotrophic factor mediates an excitoprotective effect of dietary restriction in mice. J Neurochem 2001;76:619-626. [PubMed: 11208925]

47. Yu ZF, Mattson MP. Dietary restriction and 2-deoxyglucose administration reduce focal ischemic brain damage and improve behavioral outcome: evidence for a preconditioning mechanism. $\mathbf{J}$ Neurosci Res 1999;57:830-839. [PubMed: 10467254]

48. Lee J, Duan W, Mattson MP. Evidence that brain-derived neurotrophic factor is required for basal neurogenesis and mediates, in part, the enhancement of neurogenesis by dietary restriction in the hippocampus of adult mice. J Neurochem 2002;82:1367-1375. [PubMed: 12354284]

49. Duan W, Guo Z, Jiang H, Ware M, Li XJ, Mattson MP. Dietary restriction normalizes glucose metabolism and BDNF levels, slows disease progression, and increases survival in huntingtin mutant mice. Proc Natl Acad Sci U S A 2003;100:2911-2916. [PubMed: 12589027]

50. Hock C, Heese K, Hulette C, Rosenberg C, Otten U. Region-specific neurotrophin imbalances in Alzheimer disease: decreased levels of brain-derived neurotrophic factor and increased levels of nerve growth factor in hippocampus and cortical areas. Arch Neurol 2000;57:846-851. [PubMed: 10867782]

51. Howells DW, Porritt MJ, Wong JY, Batchelor PE, Kalanins R, Hughes AJ, Donnan GA. Reduced BDNF mRNA expression in the Parkinson's disease substantia nigra. Exper Neurol 2000;166:127135. [PubMed: 11031089]

52. Hunt ND, Hyun DN, Allard JS, Minor K, Mattson MP, Ingram DK, Cabo R. Bioenergetics of aging and calorie restriction. Aging Res Rev 2006;5:125-143.

53. Qin W, Chachich M, Lane M, Roth G, Bryant M, de Cabo R, Ottinger MA, Mattison J, Ingram D, Gandy S, Pasinetti GM. Calorie restriction attenuates Alzheimer's disease type brain amyloidosis in Squirrel monkeys (Saimiri sciureus). J Alzheimers Dis 2006;10:417-22. [PubMed: 17183154]

54. Halagappa VK, Guo Z, Pearson M, Matsuoka Y, Cutler RG, Laferla FM. intermittent fasting and caloric restriction ameliorate age-related behavioral deficits in the triple-transgenic mouse model of Alzheimer's disease. Neurobiol Dis 2007;26:212-20. [PubMed: 17306982]

55. Gillette-Guyonnet, Vellas B. Caloric restriction and brain function. Curr Opin Clin Nutr Metab Care 2008;11:686-692. [PubMed: 18827571]

56. Wu P, Shen Q, Dong S, Xu Z, Tsien JZ, Hu Y. Calorie restriction ameliorates neurodegenerative phenotypes in forebrain-specific presenelin-1 and presenelin-2 double knockout mice. Neurbiol Aging 2008;29:1502-1511.

57. Levenson CW, Rich NJ. Eat less, live longer? New insights into role of calorie restriction in the brain. Nutrition review 2007;65:412-415.

58. Blandford, G.; Watkins, LB.; Mulvihil, MN. Assesing abnormal feeding behaviour in dementia: taxonomy and initial findings. In: Vellas, B.; Riviere, S.; Fitten, J., editors. weight loss and Eating 
Behaviour in Alzheimer's patients: Research and practice in Alzheiemr's Disease. SERDI; Paris: p. 49-66.

59. Riviere S, GilletteGuyonnet S, Andrieu S, Nourhashemi F, Lauque S, Cantet C, Salva A, Frisoni G, Vellas B. Cognitive function and caregiver burden: predictive factors for eating behaviour disorders in Alzheimer's disease. Inter J Geriatr Psych 2002;17:950-955.

60. Shatenstein B, Kergoat MJ, Reid I. Poor nutrient intakes during 1-year follow-up with communitydwelling older adults with early-stage Alzheimer dementia compared to cognitively intact matched controls. J Am Diet Assoc 2007;107:2091-9. [PubMed: 18060894]

61. Luchsinger JA, Gustafson DR. Adiposity and Alzheimer's disease. Curr Opin Clin Nutr Metab Care 2009;12:15-21. [PubMed: 19057182]

62. Bassett CN, Montine TJ. Lipoproteins and lipid peroxidation in Alzheimer's disease. J Nutr Health Aging 2003;7:24-29. [PubMed: 12679837]

63. Puglielli L, Tanzi RE, Kovacs DM. Alzheimer's disease: the cholesterol connection. Nat Neurosci 2003;6:345-351. [PubMed: 12658281]

64. Jarvik GP, Wijsman EM, Kukull WA, Schellenberg GD, Yu C, Larson EB. Interactions of Apolipoprotein E genotype, total cholesterol level, age, and sex in prediction of Alzheimer's disease: a case-control study. Neurology 1995;45:1092-1096. [PubMed: 7783869]

65. Petanceska SS, DeRosa S, Sharma A, Diaz N, Duff K, Tint SG, Refolo LM, Pappolla M. Changes in apolipoprotein $\mathrm{E}$ expression in response to dietary and pharmacological modulation of cholesterol. J Mol Neurosci 2003;20:395-406. [PubMed: 14501024]

66. Marshall JA, Kamboh MI, Bessesen DH, Hoag S, Hamman RF, Ferrell RE. Associations between dietary factors and serum lipids by apolipoprotein E polymorphism. Am J Clin Nutr 1996;63:87-95. [PubMed: 8604675]

67. Farrer LA, Cupples LA, Haines JL, Hyman B, Kukull WA, Mayeux R, Myers RH, PericakVance MA, Risch N, vanDuijn CM. APOE and Alzheimer Disease Meta Analysis Consortium. Effects of age, sex, and ethnicity on the association between apolipoprotein E genotype and Alzheimer disease. A meta-analysis. JAMA 1997;278:1349-1356. [PubMed: 9343467]

68. Farrer LA, Friedland RP, Bowirrat A, Waraska K, Korczyn A, Baldwin CT. Genetic and environmental epidemiology of Alzheimer's disease in arabs residing in Israel. J Mol Neurosci 2003;20:207-212. [PubMed: 14500999]

69. Petot GJ, Traore F, Debanne SM, Lerner AJ, Smyth KA, Friedland RP. Interactions of apolipoprotein E genotype and dietary fat intake of healthy older persons during mid-adult life. Metabolism 2003;52:279-281. [PubMed: 12647263]

70. LopezMiranda J, Ordovas JM, Mata P, Lichtenstein AH, Clevidence B, Judd JT, Schaefer EJ. Effect of apolipoprotein E phenotype on diet-induced lowering of plasma low density +-+lipoprotein cholesterol. J Lipid Res 1994;35:1965-1975. [PubMed: 7868975]

71. Campos H, D'Agostino M, Ordovas JM. Gene-diet interactions and plasma lipoproteins: role of apolipoprotein E and habitual saturated fat intake. Gene Epidem 2001;20:117-128.

72. Hu FB, Willett WC. Optimal diets for prevention of coronary heart disease. JAMA 2002;288:25692578. [PubMed: 12444864]

73. Lim GP, Calon F, Morihara T, Yang F, Teter B, Ubeda O, Salem N Jr, Frausty SA, Cole CM. A diet enriched with omega-3 fatty acid docosahexaenoic acid reduces amyloid burden in an aged Alzheimer's mouse model. J Neurosci 2005;25:3032-3040. [PubMed: 15788759]

74. Calon F, Lim GP, Yang F, Morihara T, Teter B, Ubeda O, Rostaing P, Triller A, Salem N Jr, Ashe KH, Frautschy SA, Cole GM. Docosahexaenoic acid protects from dendritic pathology in an Alzheimer's disease mouse mode. Neuron 2004;2:633-645. [PubMed: 15339646]

75. Kitjka K, Puskas LG, Zvara A, Hacker LJ, BarceloCoblijn G, Yeo YK, Farkas T. The Role of n-3 polyunsaturated fattyacids in the brain: modulation of rat brain gene expression by dietary expression by dietary n-3 fatty acids. Proc Natl Acad Sci USA 2002;99:2619-2624. [PubMed: 11880617]

76. Puskas LG, Kitajka K, Nyakas C, BarceloCoblijn G, Farksa T. Short-term administration of omega-3 fattyacids from fish oil results in increased transthyretin transcription in old rat hippocampus. Pro Natl Acad Sci USA 2003;100:1560-1565.

77. Schroeder F, Woodford JK, Kavecansky J, Wood WG, Joiner C. Cholesterol domains in biological membranes. Mol Membrane Biol 1995;12:113-119. 
78. Porter JA, Young KE, Beachy PA. Cholesterol modification of hedgehog signaling proteins in animal development. Science 1996;274:255-259. [PubMed: 8824192]

79. Yeagle PL. Modulation of membrane function by cholesterol. Biochimie 1991;73:1303-1310. [PubMed: 1664240]

80. Mitchell DC, Straume M, Miller JL, Litman BJ. Modulation of metarhodopsin formation by cholesterol-induced ordering of bilayer lipids. Biochemistry 1990;29:9143-9149. [PubMed: 2271584]

81. Brown MS, Goldstein JL. The SREBP pathway: regulation of cholesterol metabolism by proteolysis of a membrane-bound transcription factor. Cell 1997;89:331-340. [PubMed: 9150132]

82. Rouser G, Kritchevsky G, Yamamoto A, Baxter CF. Lipids in the nervous system of different species as a function of age: brain, spinal cord, peripheral nerve, purified whole cell preparations, and subcellular particulates: regulatory mechanisms and membrane structure. Adv Lipid Res 1972;10:261-360.

83. Sakakihara Y, Volpe JJ. Dolichol in human brain: regional and developmental aspects. J Neurochem 1985;44:1535-1540. [PubMed: 3989548]

84. Roth GS, Joseph JA, Mason RP. Membrane alterations as causes of impaired signal transduction in Alzheimer's disease and aging. Trends Neurosci 1995;18:203-206. [PubMed: 7610488]

85. Igbavboa U, Avdulov NA, Schroeder F, Wood WG. Increasing age alters transbilayer fluidity and cholesterol asymmetry in synaptic plasma membranes of mice. J Neurochem 1996;66:1717-1725. [PubMed: 8627330]

86. Lutjohann D, Breuer O, Ahlborg G, Nennesmo I, Siden A, Diczfalusy U, Bjorkhem I. Cholesterol homeostasis in human brain: evidence for an age-dependent flux of 24S-hydroxycholesterol from the brain into the circulation. Proc Natl Acad Sci U S A 1996;93:9799-9804. [PubMed: 8790411]

87. Reiss AB, Siller KA, Rahman MM, Chan ESL, Ghiso J, deLeon MJ. Chlolesterol in neurologic disorders of the elderly: stroke and Alzheimer's disease. Neurobiol Aging 2004;25:977-989. [PubMed: 15212822]

88. Mason RP, Shoemaker WJ, Shajenko L, Chambers TE, Herbette GL. Evidence for changes in the Alzheimer's disease brain cortical membrane structure mediated by cholesterol. Neurobiol Aging 1992;13:413-419. [PubMed: 1625771]

89. Jarvik GP, Austin MA, Fabsitz RR, Auwerx J, Reed T, Christian JC, Deeb S. Genetic influences on age-related change in total cholesterol, low density lipoprotein-cholesterol, and triglyceride levels: longitudinal Apolipoprotein E genotype effects. Genet Epidemiol 1994;11:375-384. [PubMed: 7813899]

90. Koudinov AR, Koudinova NV. Essential role for cholesterol in synaptic plasticity and neuronal degeneration. FASEB J 2001;15:1858-1860. [PubMed: 11481254]

91. Puglielli L, Konopka G, PackChung E, Ingano LA, Berezovska O, THyman B, Chang TY, Tanzi RE, Kovacs DM. Acyl-coenzyme A: cholesterol acyltransferase modulates the generation of the amyloid beta-peptide. Nat Cell Biol 2001;3:905-912. [PubMed: 11584272]

92. Bodovitz S, Klein WL. Cholesterol modulates alpha secretase clevage of amyloid precursor protein. J Biol Chem 1996;271:4436-4440. [PubMed: 8626795]

93. Nunan J, Small GW. Proteolytic processing of the amyloid-beta protein precursor of Alzheimer's disease. Essays Biochem 2002;38:37-49. [PubMed: 12463160]

94. Cole SL, Grudzien A, Manhart IO, Kelly BL, Oakley H, Cole RV. Statins Cause Intracellular Accumulation of Amyloid Precursor Protein, -Secretase-cleaved Fragments, and Amyloid -Peptide via an Isoprenoid-dependent Mechanism. J Biol Chem 2005;280:18755-70. [PubMed: 15718241]

95. Zhou Y, Suram A, Venugopal C, Prakasam A, Lin S, Su Y, Baolin Li B, Paul SM, Sambamurti K. Geranylgeranyl pyrophosphate stimulates -secretase to increase the generation of A $\beta$ and APP-CTF. FASEB J 2008;22:47-54. [PubMed: 17666454]

96. Refolo L, Pappolla M, Malester B, LaFrancois J, Wang R, Tint G, Sambamurti K, Bryant-Thomas T, Duff K. Hypercholesterolemia accelerates amyloid pathology in a transgenic mouse model for Alzheimer's disease amyloidosis. Neurobiol Dis 2000;7:321-31. [PubMed: 10964604]

97. Granholm AC, Bimonte-Nelson HA, Moore AB, Nelson ME, Freeman LR, Sambamurti K. Effects of a saturated fat and high cholesterol diet on memory and hippocampal morphology in the middleaged rat. J Alzheimers Dis 2008;14:133-145. [PubMed: 18560126] 
98. Patil S, Chan C. Palmitic and stearic fatty acids induce Alzheimer-like hyperphosphorylation of tau in primary rat cortical neurons. Neurosci Lett 2005;384:288-293. [PubMed: 15939536]

99. Panza F, Solfrizzi V, Colacicco AM, D'Introno A, Capurso C, Torres F, Parig AD, Capurso S, Capurso A. Mediterranean diet and cognitive decline. Public Health and Nutrition 2004;7:959-963.

100. Reaven E, Cao L, Azhar S. Effect of age on cholesterol uptake and utilization by rat adrenals: II. Lipoproteins from young and old rats. Mechanism of Ageing and Development 1994;77:27-41.

101. Arendash GW, Jensen MT, Salem N Jr, Hussei N, Cracchiolo J, Dickson A, et al. A diet high in omega-3 fatty acids does not improve orprotect cognitive performance in Alzheimer's transgenic mice. Neuroscience 2007;149:286-302. [PubMed: 17904756]

102. Pappolla MA, Bryant-Thomas TK, Herbert D, Pacheco J, Garcia FM, Manjon M, Girones X, Henry TL, Matsubara E, Zambon D, Wolozin B, Sano M, Cruz-Sanchez, Thal LJ, Petanceska SS, Refolo LM. Mild hypercholesterolemia is an early risk factor for the development of Alzheimer amyloid pathology. Neurology 2003;61:199-205. [PubMed: 12874399]

103. Mielke MM, Zandi PP, ögren M, Gustafson D, Östling S, Steen B, koog I. High total cholesterol levels in late life associated with a reduced risk of dementia. Neurology 2005;64:689-1695.

104. Sambamurti K, Granholm AC, Kindy MS, Bhat NR, Greig NH, Lahiri DK, Mintzer JE. Cholesterol and Alzheimer's Disease: Clinical and experimental models suggest interactions of different genetic, dietary and environmental risk factors. Current Drug Targets 2005;5:517-528. [PubMed: 15270198]

105. Rottkamp CA, Nunomura A, Hirai K, Sayre LM, Perry G, Smith MA. Will antioxidants fulfill their expectations for the treatment of Alzheimer disease? Mech Ageing Dev 2000;116:169-179. [PubMed: 10996017]

106. Smith MA, Harris PLR, Sayre LM, Perry G. Iron accumulation in Alzheimer's disease is a source of redox-generated free radicals. Pro Natl Acad Sci USA 1997;94:9866-9868.

107. Good PF, Peril D, Bierer LM, Schmeidler. Selective accumulation of aluminium and iron in neurofibrillary tangles of Alzheimer's disease: a laser microprobe (LAMA study). Neurology 1992;31:286-292.

108. Muma NA, Singer SM. Aluminum -induced neuropathology: transient changes in microtubuleassociated proteins. Neurotoxicol Teratol 1996;18:679-690. [PubMed: 8947945]

109. Garruto RM, Fukatsu R, Yanagihara R, Gajdusek DC, Hook G, Fiori CE. Imaging of calcium and aluminum in neurofibrillary tangle-bearing neurons in parkinsonism-dementia of Guam. Proc Natl Acad Sci U S A 1984;81:1875-1879. [PubMed: 6584922]

110. Oteiza PI. A mechanism for the stimulatory effect of aluminium on iron induced lipid peroxidation. Arch Biochem Biophys 1994;308:374-379. [PubMed: 8109967]

111. Castellani RJ, Smith MA, Nunomura A, Harris PLR, Perry G. Increased redox active iron in Alzheimer's disease failure of the copper binding protein ceruloplasmin? Free Radic Biol Med 1999;26:1508-1512. [PubMed: 10401616]

112. Rao KSJ, Rao RV, Shanmugavelu P, Menon RB. Trace elements in Alzheimer's disease brain: Anew hypothesis. Alzheimer's Rep 1999;2:241-246.

113. Sparks DL, Schreurs BG. Trace amounts of copper in water induce $\beta$-amyloid plaques and learning deficits in a rabbit model of Alzheimer's disease. Pro Natl Acad Sci USA 2003;100:11065-11069.

114. Lahiri DK, Zawia NH, Greig NH, Sambamurti K, Maloney B. Early life events may trigger biochemical pathways for Alzheimer's disease:the "LEARn"model. Biogerontology 2008;9:5-379.

115. Hegde ML, Bharathi P, Suram A, Venugopal V, Jagannathan R, Poddar P, Srinivas P, Sambamurti K, Rao KSJ, Scancar J, Messori L, Zecca L, Zatta P. Challenges Associated with Metal Chelation Therapy in Alzheimer's Disease. J Alzheimers Dis 2009;17:457-468. [PubMed: 19363258]

116. Butterfield DA, Castegna A, Drake J, Scapagnini G, Calabrese V. Vitamin E and neurodegenerative disorders associated with oxidative stress. Nutr NeuroscI 2002;5:229-239. [PubMed: 12168685]

117. Ascherio A. Antioxidants and stroke. Am J Clin Nutr 2000;72:337-338. [PubMed: 10919924]

118. Hirvonen T, Virtamo J, Korhonen P, Albanes D, Pietinen P. Intake of flavonoids, carotenoids, vitamins $\mathrm{C}$ and E, and risk of stroke in male smokers. Stroke 2000;31:2301-2306. [PubMed: 11022054] 
119. Zandi PP, Anthony JC, Khachaturian AS, Stone SV, Gustafson D, Tschanz JT, Norton MC, WelshBohmer KA, Breitner JC. Reduced risk of Alzheimer disease in users of antioxidant vitamin supplements: the Cache County Study. Arch Neurol 2004;61:82-88. [PubMed: 14732624]

120. Kedar NP. Can we prevent Parkinson's and Alzheimer's disease. J Postgrad Med 2003;49:236-245. [PubMed: 14597787]

121. Luchsinger JA, Tang MX, Shea S, Mayeux R. Antioxidant vitamin intake and risk of Alzheimer disease. Arch Neurol 2003;60:203-208. [PubMed: 12580704]

122. Cavallini L, Bindoli A, Siliprandi N. Comparative evaluation of antiperoxidative action of silymarin and other flavonoids. Pharm Res Communication 1978;10:133-136.

123. Fusco D, Colloca G, Monaco MRL, Cesari M. Effects of antioxidant supplementation on the aging process. Clin Interv Aging 2007;2:377-387. [PubMed: 18044188]

124. Joseph JA, ShukittHale B, Denisova NA, Prior RL, Cao G, Martin A, Taglialatela G, Bickford PC. Long-term dietary strawberry, spinach, or vitamin E supplementation retards the onset of agerelated neuronal signal-transduction and cognitive behavioral deficits. J Neurosci 1998;18:80478055. [PubMed: 9742171]

125. Morris MC, Evans DA, Tangney CC, Bienias JL, Wilson RS, Aggarwal NT, Scherr PA. Relation of the tocopherol forms to incident Alzheimer disease and to cognitive change. Am J Clin Nutr 2005;81:508-514. [PubMed: 15699242]

126. Peterson RC, Ronaldhomas G, Grundman M, Bennett D, Doody R, Ferris S, Galasko D, Jin S, Kaye J, Levey A, Pfeiffer E, Sano M, Christopher H, Dyck V, Thal LJ. Vitamin E and Donepezil for the treatment of mild cognitive impairment. The N Eng J Med 2005;353:2379-2388.

127. Young KW, Greenwood CE. Shift in diurnal feeding patterns in nursing home residents with Alzheimer's disease. J Gerontol A Biol Sci Med Sci 2001;56:700-706.

128. Sumien N, Forster MJ, Sohal RS. Supplementation with vitamin E fails to attenuate oxidative damage in mice. Exp Gerentol 2003;38:699-704.

129. Kontush K, Schekatolina S. Vitamin E in neurodegenerative disorders: Alzheimer's disease. Ann N Y Acad Sci 2004;1031:249-262. [PubMed: 15753151]

130. Seshadri S, Wolf PA. Homocysteine and the brain: vascular risk factor or neurotoxin? Lancet Neurol 2003;2:11. [PubMed: 12849292]

131. He K, Merchant A, Rimm EB, Rosner BA, Stampfer MJ, Willett WC, Ascherio A. Folate, vitamin B6, and B12 intakes in relation to risk of stroke among men. Stroke 2004;35:169-174. [PubMed: 14671243]

132. Leboeuf R. Homocysteine and Alzheimer's disease. J Am Diet Assoc 2003;103:304-307. [PubMed: 12616250]

133. Clarke R, Smith AD, Jobst KA, Refsum H, Sutton L, Ueland PM. Folate, vitamin B12, and serum total homocysteine levels in confirmed Alzheimer disease. Arch Neurol 1998;55:1449-1555. [PubMed: 9823829]

134. Mattson MP. Emerging neuroprotective strategies for Alzheimer's disease: dietary restriction, telomerase activation, and stem cell therapy. Exper Gerontol 2000;35:489-502. [PubMed: 10959037]

135. KrumanII TS, Kumaravel A, Lohani WA, Pedersen RG, Cutler Y, Kruman N, Haughey J, Lee M, Evans, Mattson MP. Folic acid deficiency and homocysteine impair DNA repair in hippocampal neurons and sensitize them to amyloid toxicity in experimental models of Alzheimer's disease. $\mathrm{J}$ Neurosci 2002;22:1752-1762. [PubMed: 11880504]

136. Baydas G, Kutlu S, Naziroglu M, Canpolat S, Sandal S, Ozcan M, Kelestimur H. Inhibitory effects of melatonin on neural lipid peroxidation induced by intracerebroventricularly administered homocysteine. J Pineal Res 2003;34:36-39. [PubMed: 12485370]

137. Kruman II, Culmsee C, Chan SL, Kruman Y, Guo Z, Penix L, Mattson MP. Homocysteine elicits a DNA damage response in neurons that promotes apoptosis and hypersensitivity to excitotoxicity. J Neurosci 2000;20:6920-6926. [PubMed: 10995836]

138. Fuso A, Seminara L, Rosaria A, Cavallaro, Anselmi FD, Scarpa S. S-adenosylmethionine/ homocysteine cycle alternations modify DNA methylation status with consequent deregulation of PS1 and BACE and beta-amyloid production. Mol Cell Neurosci 2005;28:195-204. 139. [PubMed: 15607954] 
139. Fuso A, Nicolia V, Cavallaro RA, Ricceri L, D'Anselmi F, Coluccia P, Calamandrei G, Scarpa S. B-vitamin deprivation induces hyperhomocysteinemia and brain S-adenosylhomocysteine, depletes brain S-adenosylmethionine, and enhances PS1 and BACE expression and amyloid-beta deposition in mice. Mol Cell Neurosci 2008;37:731-46. [PubMed: 18243734]

140. Pacheco-Quinto J, Rodriguez de Turco EB, DeRosa S, Howarda A, Cruz-Sanchezc A, Sambamurti K, Refoloe L, Petanceska S, Pappolla MA. Hyperhomocysteinemic Alzheimer's mouse model of amyloidosis shows increased brain amyloid $\beta$ peptide levels. Neurobiol Dis 2006;22:651-656. [PubMed: 16516482]

141. Jang JH, Surh YJ. Protective effect of resveratrol on beta-amyloid-induced oxidative PC12 cell death. Free Radic Biol Med 2003;34:1100-1110. [PubMed: 12684095]

142. Mandel S, Amit T, Bar O, Youdim MB. Iron dydregulation in Alzheimers disease: multimodal brain permeable iron chelating drugs possessing neuroprotective -neurorescue and ammyloid precursor protein -processing regulatory activities as therapeutic agents. Prog Neurobiol 2007;82:348-360. [PubMed: 17659826]

143. Van Acker SA, Vanden Berg DJ, Tromp MN, Griffioen DH, Van Bennekom WP, Vander Vijgh WJ, Bast A. Structural aspects of antioxidant activity of flavonoids. Free Radic Biol Med 1996;20:331-342. [PubMed: 8720903]

144. Levites Y, Weinreb O, Maor G, Youdim MBH, Mandel S. Green tea polyphenol(-) epigallocatechin-3-gallate prevents N-methyl-4-phenyl-1,2,3,6-tetrahydropyridineinduceddopaminergicneurodegeneration. J Neurochem 2001;78:1073-1082. [PubMed: 11553681]

145. Wang J, Ho L, Zhao W, Ono K, Rosenberg C, Chen L, et al. Grape derived ployphenolics prevent A $\beta$ oligomerization and attenuate cognitive deterioration in a mouse model of Alzheimer'd disease. J Neurosci 2008;28:6388-6392. [PubMed: 18562609]

146. Salah N, Miller NJ, Paganga G, Tigburg L, Bolwel GP, RiceEvans C. Polyphenolic flavanols as scavengers of aqueous phase radicals and as chain -breaking antioxidants. Arch Biochem Biophys 1995;322:339-346. [PubMed: 7574706]

147. Morel I, Lescoat G, Cogrel P, Sergent O, Pasdeloup N, Brissot P, Cillard P, Cillard J. Antioxidant and iron chelating activities of the flavonoids carechin,quercetin and diosmetin on iron-loaded rat hepatocyte cultures. Biochem Pharmocol 1998;45:13-19.

148. Thompson M, Williams CR, Elliot GE. Stability of flavonoids complexes of copper (II) and flavonoids antioxidant activity. Ann Chim Acta 1976;85:375-381.

149. Levites Y, Amit T, Youdim MB, Mandel S. Involvement of protein kinase C activation and cell survival/ cell cycle genes in green tea polyphenol (-)-epigallocatechin 3-gallate neuroprotective action. J Biol Chem 2002;277:30574-30580. [PubMed: 12058035]

150. Rezai-Zadeh K, Shytle D, Sun N, Mori T, Hou H, Jeanniton D, Ehrhart J, Townsend K, Zeng J, Morgan D, Hardy J, Town T, Tan J. Green tea epigallocatechin-3-gallate (EGCG) modulates amyloid precursor protein cleavage and reduces cerebral amyloidosis in Alzheimer transgenic mice. J Neurosci 2005;25:8807-14. [PubMed: 16177050]

151. Ruitenberg A, vanSwieten JC, Witteman JC, Mehta KM, vanDuijn CM, Hofman A, Breteler MM. Alcohol consumption and risk of dementia: the Rotterdam Study. Lancet 2002;359:281-286. [PubMed: 11830193]

152. Mukamal KJ, Kuller LH, Fitzpatrick AL, Longstreth WT Jr, Mittleman MA, Siscovick DS. Prospective study of alcohol consumption and risk of dementia in older adults. JAMA 2003;289:1405-1413. [PubMed: 12636463]

153. Galanis DJ, Joseph C, Masaki KH, Petrovitch H, Ross GW, White L. Longitudinal study of drinking and cognitive performance in elderly Japanese American men: the Honolulu-Asia Aging Study. Am J Public Health 2000;90:1254-1259. [PubMed: 10937006]

154. Luchsinger JA, Mayeux R. Cardiovascular risk factors and Alzheimer's disease. Curr Atheroscle Rep 2004;6:261-266.

155. Truelsen T, Thudium D, Gronbaek M. Copenhagen City Heart Study, Amount and type of alcohol and risk of dementia: the Copenhagen City Heart Study. Neurology 2002;59:1313-1319. [PubMed: 12427876] 
156. Jaatinen P, Riikonen J, Riihioja P, Kajander O, Hervonen. A Interaction of aging and intermittent ethanol exposure on brain cytochrome c oxidase activity levels. Alcohol 2003;29:91-100. [PubMed: 12782250]

157. Sacco RL, Elkind M, BodenAlbala B, Lin IF, Kargman DE, Hauser WA, Shea S, Paik MC. The protective effect of moderate alcohol consumption on ischemic stroke. JAMA 1999;281:53-60. [PubMed: 9892451]

158. Lindsay D, Laurin R, Verreault R, Hebert B, Helliwell, Hill GB, McDowell I. Risk factors for Alzheimer's disease: a prospective analysis from the Canadian Study of Health and Aging. Am J Epidem 2002;156:445-453.

159. Orgogozo JM, Dartigues JF, Lafont S, Letenneur L, Commenges D, Salamon R, Renaud S, Breteler MB. Wine consumption and dementia in the elderly: a prospective community study in the Bordeaux area. Review Neurol 1997;153:185-192.

160. Savaskan E, Olivieri G, Meier F, Seifritz E, WirzJustice A, MullerSpahn FR. Wine ingredient resveratrol protects from beta-amyloid neurotoxicity. Gerontology 2003;49:380-383. [PubMed: 14624067]

161. Han YS, Zheng WH, Bastianetto S, Chabot JG, Quirion R. Neuroprotective effects of resveratrol against beta-amyloid-induced neurotoxicity in rat hippocampal neurons: involvement of protein kinase C. Bringham. J Pharmacol 2004;141:997-1005.

162. Marambaud P, Zhao H, Davies P. Resveratrol promotes clearance of Alzheimer's disease amyloidbeta peptides. J Biol Chem 2005;280:37377-37382. [PubMed: 16162502]

163. deVrij FM, Fischer DF, vanLeeuwen FW, Hol EM. Protein quality control in Alzheimer's disease by the ubiquitin proteasome system. Prog Neurobiol 2004;74:249-270. [PubMed: 15582222]

164. Guarente L. SIR2 and aging--the exception that proves the rule. Trend Genet 2001;17:391-392.

165. Araki T, Sasaki Y, Milbrandt J. Increased nuclear NAD biosynthesis and SIRT1 activation prevent axonal degeneration. Science 2004;13:1010-1013. [PubMed: 15310905]

166. Hoult J, Moroney MA, Paya M. Actions of flavonoids and coumarins on lipoxygenase and cyclooxygenase. Method Enzymol 1994;234:443-454.

167. Resnick B, Junlapeeya P. Falls in a community of older adults: findings and implications for practice. Application of Nursing Research 2004;17:81-91.

168. Wenzel E, Somoza V. Metabolism and bioavailability of trans-resveratrol. Mol Nutr Food Res 2005;49:472-481. [PubMed: 15779070]

169. Gescher AJ, Steward WP. Relationship between mechanisms,bioavailibility, and preclinicalchemopreventive effi cacy ofresveratrol: a conundrum. Cancer Epidemiol Biomarkers Prev 2003;12:953-957. [PubMed: 14578128]

170. Baur JA, Sinclair DA. Therapeutic potential of resveratrol:the in vivo evidence. Nat Rev Drug Discov 2006;5:493-506. [PubMed: 16732220]

171. Walle T, Hsieh F, Delegge MH, O JE Jr, Walle UK. Highabsorption but very low bioavailability of oral resveratrol in humans. Drug Metab Dispos 2004;32:1377-1382. [PubMed: 15333514]

172. Soleas GJ, Angelini M, Grass L, Diamandis EP, Goldberg DM. Absorption of trans -resveratrol in rats. Methods Enzymol 2001;335:145-154. [PubMed: 11400363]

173. Vingtdeux V, Dreses-Werringloer U, Zhao H, Davies P, Marambaud P. Therapeutic potential of resveratrol in Alzheimer's disease. BMC Neurosci 2008;9:S6. [PubMed: 19090994]

174. Karuppagounder SS, Pinto JT, Xu H, Chen HL, Beal MF, Gibson GE. Dietary supplementation with resveratrol reduces plaque pathology in a transgenic model of Alzheimer's disease. Neurochem Int 2008;54:111-118. [PubMed: 19041676]

175. Ono K, Condron MM, Ho L, Wang J, Zhao W, Pasinetti GM. Effects of grape seed-derived ployphenols on Amyloid beta protein self-assembly and cytotoxicity. J Biol Chem 2008;283:32176-32187. [PubMed: 18815129]

176. Kelloff GJ, Crowell JA, Steele VE, LubetMalone RA, Boone WA, Kopelovich L, Hawk ET, Lieberman R, Lawrence JA, Ali JL, Viner CC, Sigman CW. Progress in cancer chemoprevention: development of diet-derived chemopreventive agents. J Nutr 2000;130:467S-471S. [PubMed: 10721931] 
177. Ganguli M, Chandra V, Kamboh MI, Johnston JM, Dodge HH, Thelma BK, Juyal RC, Pandav R, Belle S, DeKosky ST. Apolipoprotein E polymorphism and Alzheimer disease: The Indo-US CrossNational Dementia Study. Arch Neurol 2000;57:824-830. [PubMed: 10867779]

178. Dheen ST, Kaur C, Ling EA. Microglial activation and its implications in the brain diseases. Curr Med Chem 2007;14:1189-1197. [PubMed: 17504139]

179. Rogers J, Webster S, Lue LF, Brachova L, Civin WH, Emmerling M, Shivers B, Walker D, McGeer. Inflammation and Alzheimer's disease pathogenesis. Neurobiol Aging 1996;17:681-686. [PubMed: 8892340]

180. Breitner JC, Welsh KA, Helms MJ, Gaskel PC, Gau BA, Roses AD, Pericak-Vance MA, Saunders AM. Delayed onset of Alzheimer's disease with nonsteroidal anti-inflammatory and histamine H2 blocking drugs. Neurobiol Aging 1995;16:523-530. [PubMed: 8544901]

181. Bjorkman D. Nonsteroidal anti-inflammatory drug-associated toxicity of the liver, lower gastrointestinal tract, and esophagus. Am J Med 1998;2:17-21.

182. McGettigan P, Henry D. Current problems with non-specific COX inhibitors. Curr Pharmocol Design 2000;6:1693-1724.

183. MartinAragon S, Benedi JM, Villar AM. Modifications on antioxidant capacity and lipid peroxidation in mice under fraxetin treatment. J Pharm Pharmacol 1997;49:49-52. [PubMed: 9120770]

184. Sreejayan, Rao MN. Nitric oxide scavenging by curcuminoids. J Pharm Pharmacol 1997;49:105107. [PubMed: 9120760]

185. Frautschy SA, Hu W, Kim P, Miller SA, Chu T, HarrisWhite ME, Cole GM. Phenolic antiinflammatory antioxidant reversal of Abeta-induced cognitive deficits and neuropathology. Neurobiol Aging 2001;22:993-1005. [PubMed: 11755008]

186. Lim GP, Chu T, Yang F, Beech W, Frautschy SA, Cole GM. The curry spice curcumin reduces oxidative damage and amyloid pathology in an Alzheimer transgenic mouse. J Neurosci 2001;21:8370-8377. [PubMed: 11606625]

187. Kumar A, Singh A. Possible nitric oxide modulation in protective effect of Curcumin (Curcumin longa, Zingiberaceae) against sleep pdeprivation induced behavioural alterations and oxidative damage in mice. Phytomedicine 2008;15:577-586. [PubMed: 18586477]

188. Ono K, Hasegawa K, Yoshiike Y, Takashima A, Yamada M, Naik H. Nordihydroguaiaretic acid potently breaks down pre-formed Alzheimer's beta-amyloid fibrils in vitro. J Neurochem 2002;81:434-440. [PubMed: 12065652]

189. Rajeswari A. Curcumin protects mouse brain from oxidative stress caused by 1-methyl-4phenyl-1,2,3,6-tetrahydropyridine. Eur Rev Med Pharmacol Sci 2006;10:157-161. [PubMed: 16910344]

190. Kumar A, Naidu PS, Seghal N, Padi SS. Effect of curcumin on intracerebroventricular colchicineinduced cognitive impairment and oxidative stress in rats. J Med Food 2007;10:486-494. [PubMed: 17887943]

191. Daniel S, Limson JL, Dairm A, Watkinson GM, Daya S. Through metal binding, curcumin protects against lead induced lipid peroxidation in rat brain homogenates and against lead induced tissue damage in rat brain. J Inorg Biochem 2004;98:266-275. [PubMed: 14729307]

192. Corder EH, Saunders AM, Strittmatter WJ, Schmechel DE, Gaskell PC, Small GW, Roses AD, Haines JL, Pericak-Vance MA. Gene dose of apolipoprotein E type 4 allele and the risk of Alzheimer's disease in late onset families. Science 1993;261:921-923. [PubMed: 8346443]

193. Hofman A, Ott A, Breteler MM, Bots ML, Slooter AJ, vanHarskamp F, vanDuijn CN, VanBroeckhoven C, Grobbee DE. Atherosclerosis, apolipoprotein E, and prevalence of dementia and Alzheimer's disease in the Rotterdam Study. Lancet 1997;349:151-154. [PubMed: 9111537]

194. Hara RO, Yesavage JA, Kraemer HC, Mauricio M, Friedman LF, Murphy GM Jr. The APOE epsilon4 allele is associated with decline on delayed recall performance in community-dwelling older adults. J Am Geriatr Soc 1998;46:1493-1498. [PubMed: 9848808]

195. Caselli RJ, GraffRadford NR, Reiman EM, Weaver A, Osborne D, Lucas J, Uecker A, Thibodeau SN. Preclinical memory decline in cognitively normal apolipoprotein E-epsilon4 homozygotes. Neurology 1999;53:201-207. [PubMed: 10408560] 
196. Greenwood CE, Tam C, Chan M, Young KWH, Binns MA, Reekum RM. Behavioural disturbances, not cognitive deterioration, are associated with altered good selection in seniors with Alzheimer's disease. The J of Gerantol A Biol Sci Med Sci 2005;60:499-505.

197. Joseph JA, Shukitt-Hale B, Willis LM. Grape juice, berries, and walnuts affect brain aging and behavior. J Nutr 2009;139:1813S-7S. [PubMed: 19640963]

198. Oken BS, Storzbach DM, Kaye JA. The efficacy of Ginkgo biloba on cognitive function in Alzheimer disease. Arch Neurol 1998;55:1409-15. [PubMed: 9823823]

199. Joshi H, Parle M. Nardostachys jatamansi improves learning and memory in mice. J Med Food 2006;9:113-8. [PubMed: 16579738]

200. Vasudevan M, Parle M. Effect of Anwala churna (Emblica officinalis GAERTN): an ayurvedic preparation on memory deficit rats. Yakugaku Zasshi 2007;12:71701-7. 


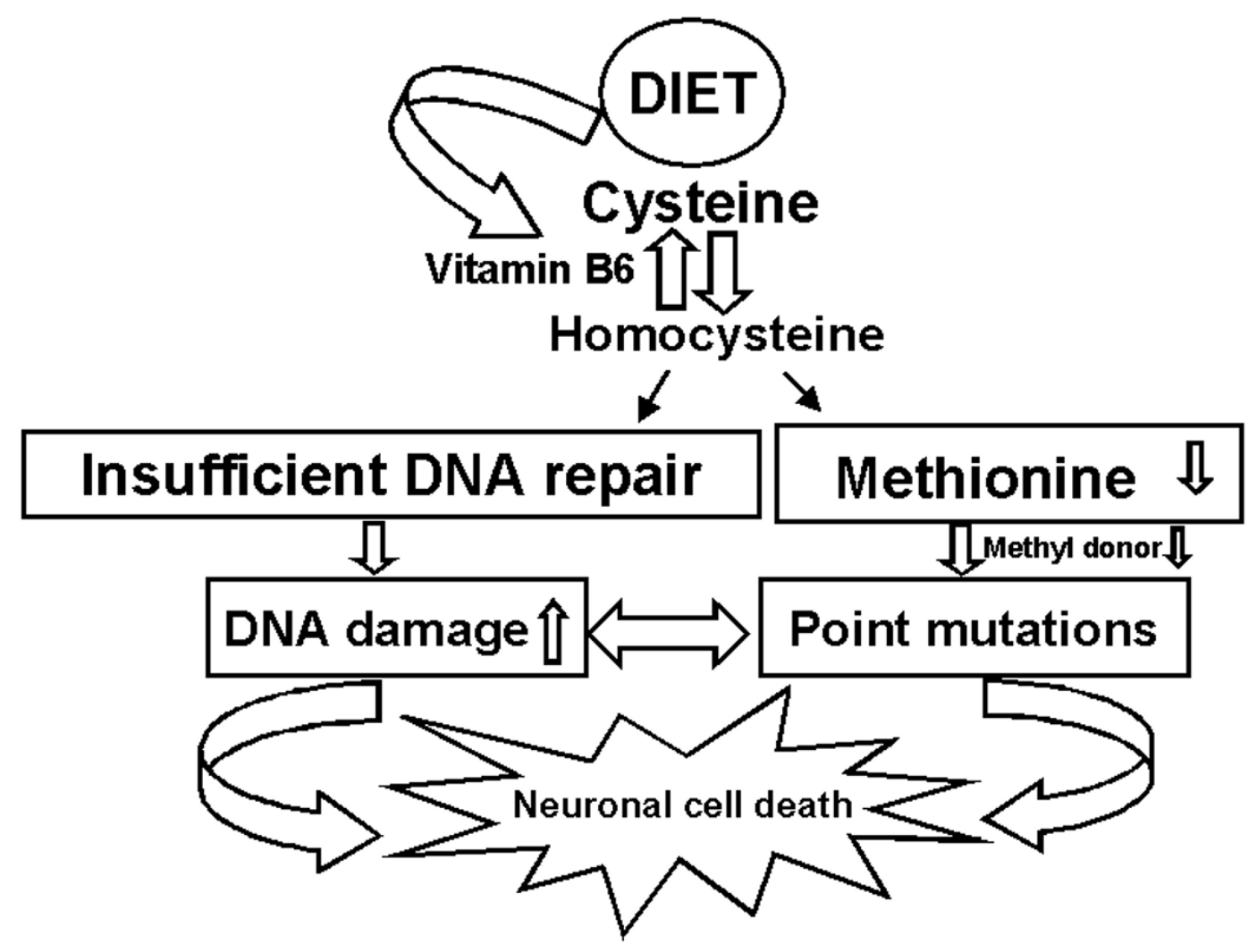

Figure 1.

The role of homocysteine in AD: Vitamin B6 acts as a cofactor in the maintenance of homeostasis between homocysteine and cysteine. Any imbalance in the vitamin B6 levels alters the balance between homocysteine to cysteine. The higher homocysteine levels may cause insufficient DNA repair leading to accumulation of DNA strand breaks. This may lead to neuronal cell dysfunction. 


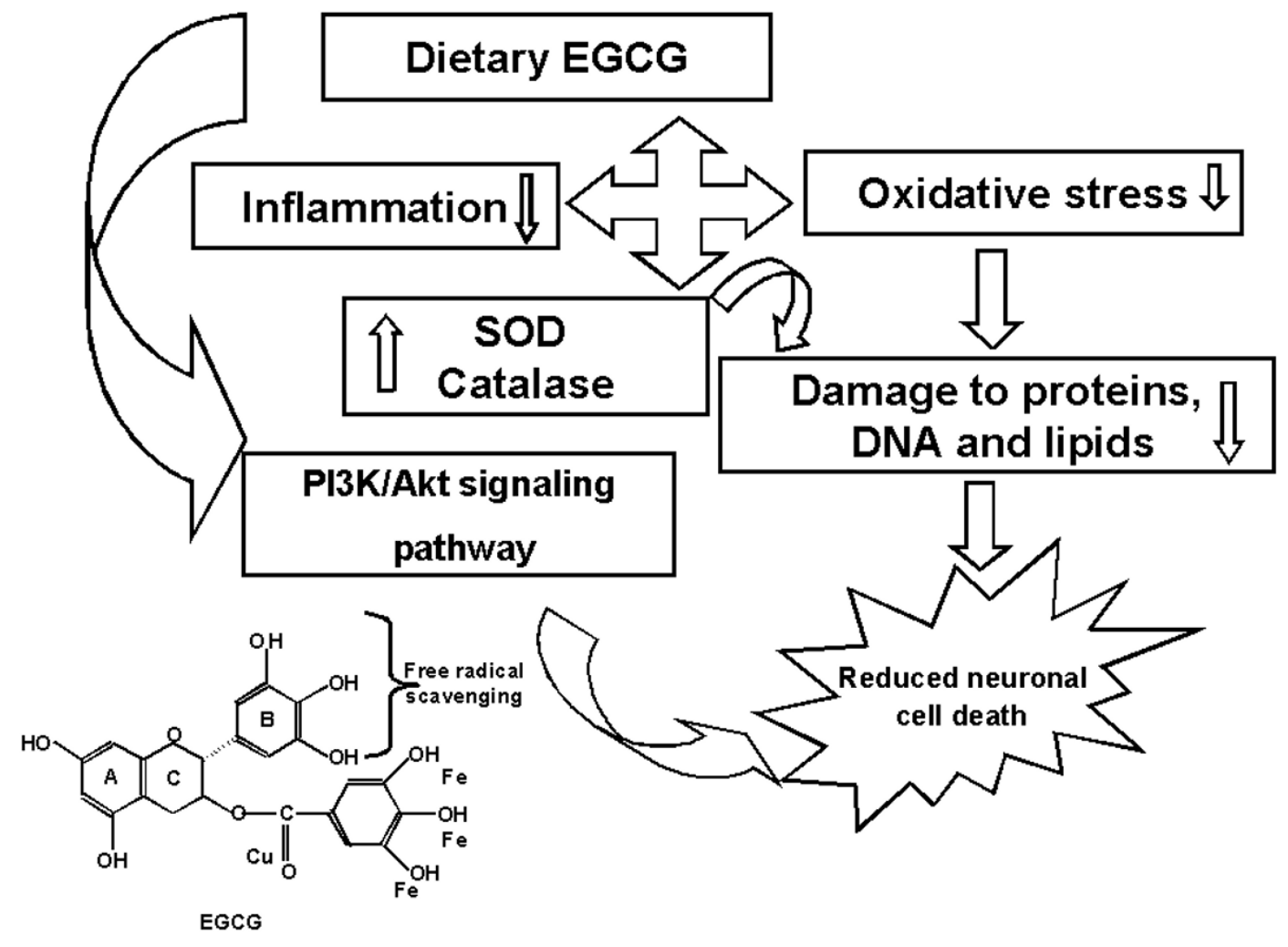

Figure 2.

EGCG's mode of action: Environmental factors such as metals cause oxidative stress, leading to protein, lipid, and DNA damage. EGCG is known to chelate transition metals like Fe and $\mathrm{Cu}$, there by prevents oxidative stress. EGCG also acts as an anti-inflammatory molecule and increases the activity of SOD and Catalase. EGCG induces the PI3K/Akt-signaling pathway, and this pathway has a pivotal role in neuronal cell survival. 


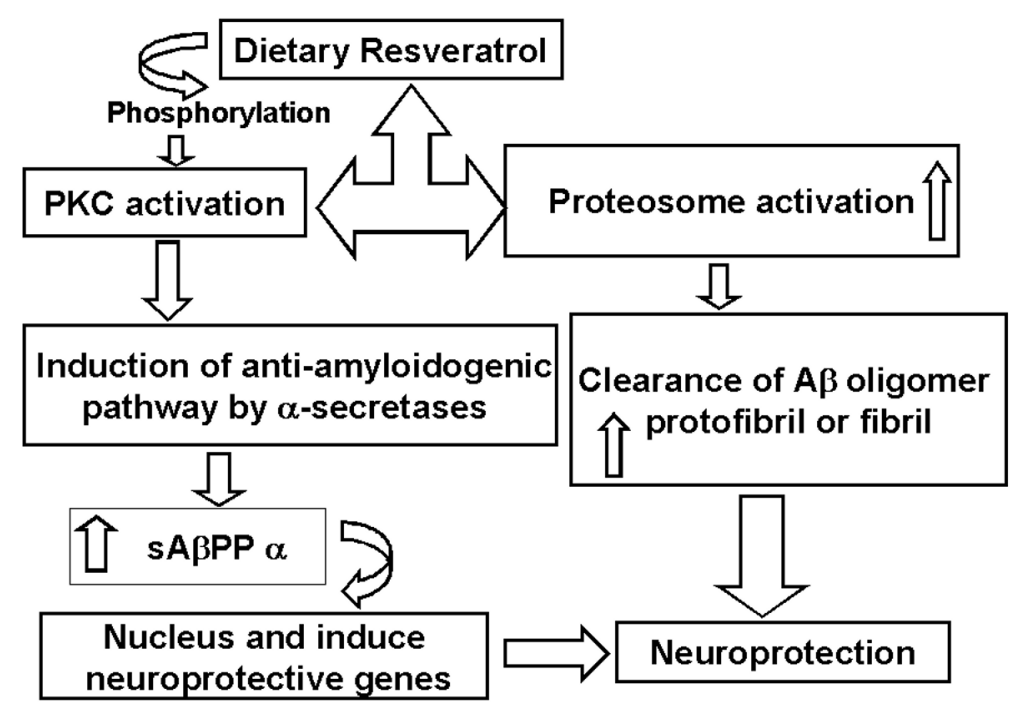

Figure 3.

The role of resveratrol in modulating neurodegeneration: Resveratrol favors phosphorylation in PKC. This activates the non-amyloidogenic pathway of $A \beta P P$ cleavage, and this leads to reduction in $\mathrm{A} \beta$ formation. $\mathrm{A} \beta \beta \mathrm{PP} \alpha$, which is a product of $\mathrm{A} \beta \mathrm{PP}$ cleavage, gets translocated to the nucleus and modulate the genes. Resveratrol also nonspecifically stimulates proteosomes, which helps in clearing A $\beta$. All these events favor neuronal cell survival. 


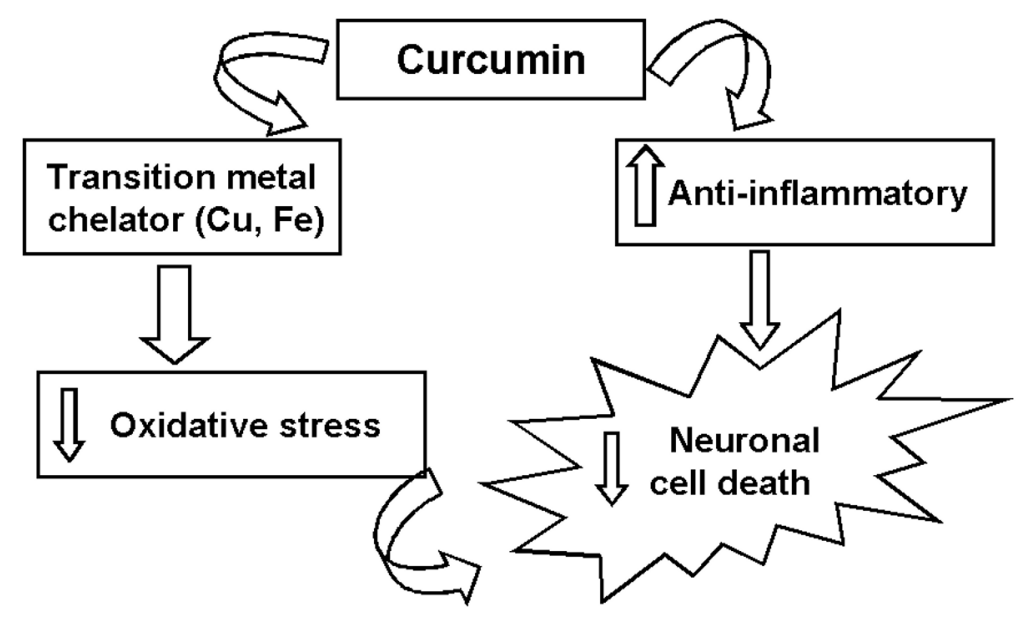

Figure 4.

The diverse effects of curcumin in combating neurodegeneration: Curcumin has multiple biological effects. It chelates transition metals ( $\mathrm{Fe}$ and $\mathrm{Cu}$ ) and acts as an antioxidant and antiinflammatory molecule. Curcumin may protect the cells from oxidative stress. 
Table 1

Studies on diet and neurochemical effects

\begin{tabular}{|c|c|c|c|c|}
\hline SI No & Brain food & Active principle & Effect/function & References \\
\hline 1 & Blueberries & flavonoids & Cognition, memory, and coordination & [197] \\
\hline 2 & Fish & Omega-3 fatty acids (DHA and EPA) & Reduces amyloid pathology by 70\% (mice) & [73] \\
\hline 3 & Turmeric & curcumin & Antioxidant, anti-inflammatory, anti-amyloid & [186] \\
\hline 4 & Green tea & EGCG (a polyphenol) & Antioxidant, anti-inflammatory & Antioxidant, anti-inflammatory \\
\hline 5 & Red wine & resveratrol & Antioxidant & Antioxidant \\
\hline 6 & Ginkgo biloba & flavonoids and terpenoids & Antioxidant & [198] \\
\hline 7 & Tomato & Ferulic acid & Antioxidant & [199] \\
\hline 8 & Amla & Vitamin C & Antioxidant & [27] \\
\hline 9 & Meat & Vitamin E & [27] \\
\hline 10 & Fruits and vegetables & & & \\
\hline
\end{tabular}

